\begin{tabular}{|l|l|l||}
\hline \multicolumn{2}{|c|}{ PublisherInfo } \\
\hline \hline PublisherName & $:$ & BioMed Central \\
\hline \hline PublisherLocation & $:$ & London \\
\hline \hline PublisherImprintName & $:$ & BioMed Central \\
\hline \hline
\end{tabular}

\title{
Continuous plasmafiltration in sepsis syndrome
}

\begin{tabular}{|l|l|l||}
\hline \multicolumn{2}{|c||}{ ArticleInfo } \\
\hline \hline ArticleID & $:$ & 4174 \\
\hline \hline ArticleDOI & $:$ & $10.1186 /$ ccf-1999-2343 \\
\hline \hline ArticleCitationID & $:$ & 2343 \\
\hline \hline ArticleSequenceNumber & $:$ & 33 \\
\hline \hline ArticleCategory & $:$ & Paper Report \\
\hline \hline ArticleFirstPage & $:$ & 1 \\
\hline \hline ArticleLastPage & $:$ & 3 \\
\hline \hline & $:$ & RegistrationDate : 1999-11-29 \\
ArticleHistory & $:$ & OnlineDate $1999-11-29$ \\
\hline \hline ArticleCopyright & $:$ & Current Science Ltd1999 \\
\hline \hline ArticleGrants & $:$ & \\
\hline \hline ArticleContext & $:$ & 1305422 \\
\hline \hline
\end{tabular}




\section{Keywords}

Acute phase protein, albumins, cytokines, eicosanoids, inflammation, mortality, multiple organ failure, plasmapheresis, randomised controlled trial, sepsis

\section{Comments}

Although randomised, this was a small study (30 patients). Neither difference in mortality nor number of organs failing reached statistically significant levels. The authors make no mention of any complications associated with PF.The acute phase response has evolutionary benefit and so, maybe, it is not surprising that a reduction in inflammatory markers has no beneficial effect on mortality.

\section{Introduction}

The clinical features of severe infection are known to be caused by host inflammatory responses (humoral and cellular factors). Previous trials to modulate this response (steroids, monoclonal antibodies to endotoxin) have shown no increase in survival.Plasma exchange has been used in patients with fulminant meningococcal septicaemia and was associated with improved patient survival. Animal studies of plasmafiltration in sepsis have also had promising results.

\section{Aims}

This prospective, randomised controlled trial aimed to investigate the effect, on humoral inflammation factors, of $34 \mathrm{~h}$ of plasmafiltration (plasma exchange using a large-pore hemofilter).

\section{Methods}

Adults and children with sepsis syndrome (as defined in the study) were randomised to conventional treatment or conventional treatment with plasmafiltration (PF). The patients were also assessed for 
immunocompetence (from APACHE II scores) and this was used in the randomisation process.Outcome at 14 days and survival at the last time of review were recorded. The number of failing organs for the first 7 days was also assessed. Assays were taken for acute phase proteins, inflammatory mediators and cytokines at defined time points.

\section{Results}

In total, 30 patients were enrolled in the study. There was no difference in mortality at 14 days. The PF group had fewer organs failing at 7 days but this was not statistically significant.PF did not affect concentrations of the majority of the cytokines studied, with a minority being lowered by PF.

\section{Discussion}

The authors felt that PF was effective in attenuating the acute phase response in sepsis. They also suggested it might be beneficial, as PF was associated with fewer organs failing at 7 days.

\section{References}

1. Reeves JH, Butt WW, Shann F, Layton JE, Stewart A, Waring PM, Presneill JJ: Continuous plasmafiltration in sepsis syndrome. Crit Care Med . 1999, 27: 2096-2104.

This PDF file was created after publication. 